\title{
Inequality, Gender Gaps and Economic Growth: Comparative Evidence for Sub-Saharan Africa
}




\section{WP/16/111}

\section{IMF Working Paper}

Inequality, Gender Gaps and Economic Growth: Comparative Evidence for Sub-Saharan Africa

by Dalia Hakura, Mumtaz Hussain, Monique Newiak, Vimal Thakoor, and Fan Yang 


\title{
IMF Working Paper
}

$\mathrm{WP} / 16 / 111$

\author{
African Department
}

\section{Inequality, Gender Gaps and Economic Growth: Comparative Evidence for Sub-Saharan Africa}

\section{Prepared by Dalia Hakura, Mumtaz Hussain, Monique Newiak, Vimal Thakoor, and Fan Yang ${ }^{1}$}

Authorized for distribution by Céline Allard

June 2016

\begin{abstract}
IMF Working Papers describe research in progress by the author(s) and are published to elicit comments and to encourage debate. The views expressed in IMF Working Papers are those of the author(s) and do not necessarily represent the views of the IMF, its Executive Board, or IMF management.
\end{abstract}

\begin{abstract}
A growing body of empirical evidence suggests that inequality — income or gender related — can impede economic growth. Using dynamic panel regressions and new time series data, this paper finds that both income and gender inequalities, including from legal gender-based restrictions, are jointly negatively associated with per capita GDP growth. Examining the relationship for countries at different stages of development, we find that this effect prevails mainly in lower income countries. In particular, per capita income growth in sub-Saharan Africa could be higher by as much as 0.9 percentage points on average if inequality was reduced to the levels observed in the fastgrowing emerging Asian countries. High levels of income inequality in sub-Saharan Africa appear partly driven by structural features. However, the paper's findings show that policies that influence the opportunities of low-income households and women to participate in economic activities also matter and, therefore, if well-designed and targeted, could play a role in alleviating inequalities.
\end{abstract}

JEL Classification Numbers: O1, O4.

Keywords: Income inequality, gender inequality, economic growth, and sub-Saharan Africa

Authors E-Mail Address: dhakura@imf.org; mhussain@imf.org; mnewiak@imf.org; jthakoor@,imf.org; fyang2@imf.org

\footnotetext{
${ }^{1}$ The authors thank Céline Allard, Christine Dieterich, Clara Mira, David Robinson, Abebe Aemro Selassie, Alun Thomas and other IMF colleagues for helpful comments, Cleary Haines and Azanaw Mengistu for excellent research assistance, and Natasha Minges and Charlotte Vazquez for excellent editorial support. The research underlying this paper was initiated in the context of the preparation of the October 2015 sub-Saharan Africa Regional Economic Outlook chapter on "Inequality and Economic Outcomes in Sub-Saharan Africa." All remaining errors are our own.
} 


\section{Table of Contents}

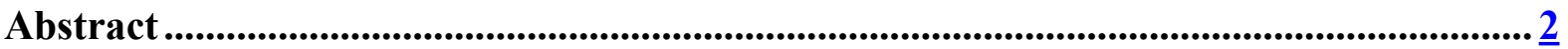

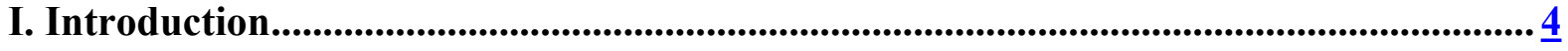

II. Data And Stylized Facts: Trends In Income And Gender Inequalities ......................... $\underline{5}$

III. Inequality And Growth Revisited ........................................................................... $\underline{8}$

A. Selective Literature Review: Income Inequality and Growth ….................................. $\underline{8}$

B. Selective Literature Review: Gender Inequality and Growth ........................................ $\frac{8}{9}$

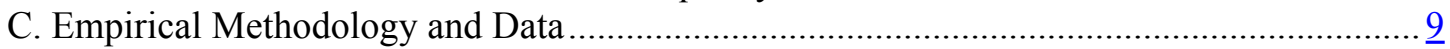

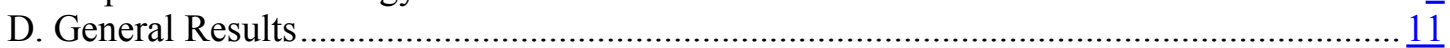

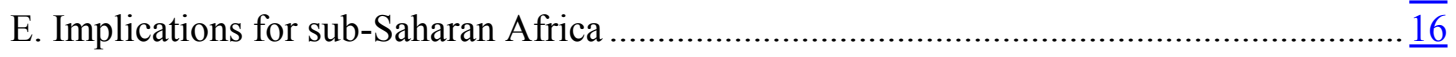

IV. What Drives Income Inequality?........................................................................................... 18

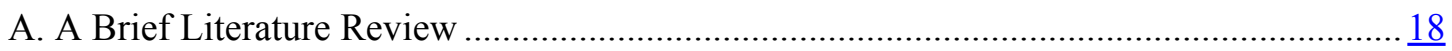

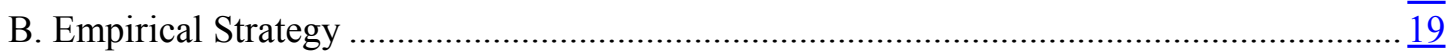

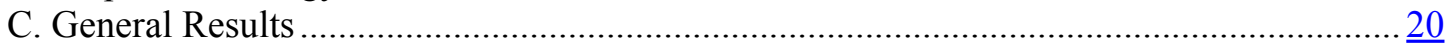

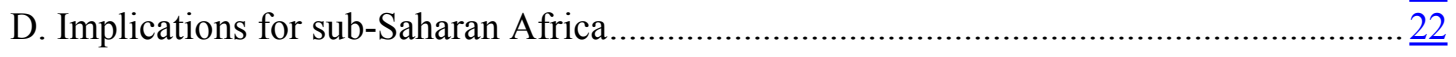

V. Conclusions ..................................................................................................................................... 2

Appendix 1. Country Coverage....................................................................................................... 27

\section{Figures}

1. Selected Regions: Gini Index of Net Income Inequality, 1980-2011 ……....................................

2. Selected Regions: Gender Inequality Index, Average 1990-2010 …...........................................

3. Selected Regions: Female Legal Rights Index, 1980-2010 …....................................................

4. Sub-Saharan Africa: Kuznets Curve, GDP per Capita and Gini Coefficient .................................. $\frac{7}{7}$

5. Sub-Saharan Africa: Income Inequality and Gender Inequality, 1990-2010 ................................ 7

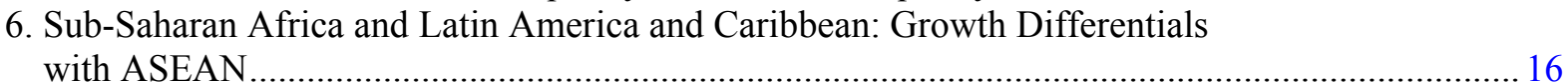

7. Subgroups of Sub-Saharan Africa: Growth Differential with ASEAN Countries .......................... 11

\section{Tables}

1. Growth, Inequality and Gender Inequality: System GMM Results from Baseline Model............... 12

2. Growth, Inequality ad Gender Inequality: GMM Results from Extended Model ......................... $\frac{15}{15}$

3. Various Regressions of Determinants of Change in Inequality (Net Gini) ................................... 21

\section{Appendix Tables}

1. Description of Variables for the Regressions Assessing the Growth Effects of Income

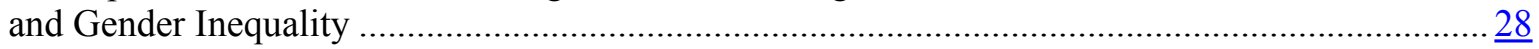

2. Description of Variables for the Regressions Assessing the Determinants of Change in Income Inequality 


\section{INTRODUCTION}

Notwithstanding the robust growth achieved over the past two decades, poverty and inequality continue to remain high in sub-Saharan Africa. Income inequality has moved little and remains the second highest in the world behind Latin America and the Caribbean region. Similarly, gender inequality in the sub-Saharan Africa region remains one of the highest and is declining slower than in other regions.

The growing empirical evidence regarding the adverse effects of income and gender inequalities on economic growth raises questions regarding its impact and persistence in sub-Saharan Africa. Thus, the first objective of this paper is to investigate the impact high inequality has had on the region's growth performance. Second, the paper aims to investigate the drivers behind income inequality as well as factors explaining its persistence. This can better inform policy making to foster inclusive growth and progress towards the Sustainable Development Goals (SDGs), which include the objectives of reducing income and gender inequalities.

By making use of newly available data, this paper differs from others by testing for the joint effects of income and gender inequality on growth at different stages of development. Recent empirical work has mainly focused on the effect of one dimension of inequality at a time (Ostry, Berg, and Tsangarides 2014; Gonzales and others 2015b) and has not specifically focused on the implications for sub-Saharan Africa. A number of studies also note that the growth-inequality link is likely to be non-linear at different levels of development (Castello 2010), and previous empirical work tends to find a negative association between growth and income inequality only below a certain threshold of income per capita (Neves and Silva 2013). To account for this possible nonlinearity, we allow for the relationship to be different between low-income countries and the other countries in the sample. Our analysis thus tests for the joint effects of both concepts of inequality while allowing to test whether the growth-inequality relationship varies between low-income and other countries (low-income, fragile, and middle-income and oil exporting) in general.

\section{The main findings of this paper are four-fold:}

- Using system-GMM estimations, income and gender inequality are found to jointly impede growth mostly in the initial stages of development, resulting in large growth losses in subSaharan Africa. These findings are robust to alternative measures of income and gender inequality and to variations in the controls in the growth regressions.

- Examining the effects of gender inequality, including from legal gender-related restrictions, and income inequality in a large global panel over the last two decades, we find that further progress in reducing income and gender inequality could deliver significant sustained growth dividends, particularly for low-income countries.

- A growth decomposition analysis highlights that average annual GDP per capita growth in sub-Saharan African countries could be higher by as much as 0.9 percentage points if income and gender inequality were reduced to the levels observed in the fast-growing Association of South East Asian Nations (ASEAN). By contrast, the analysis finds that the growth shortfall of Latin America and the Caribbean with ASEAN is mainly explained by income inequality. 
- Both structural factors and policies have been driving changes in income inequality over time, but the relevant factors differ by region and level of development. Concerning the high levels of income inequality in sub-Saharan Africa, we find that they are partly driven by the structural features of the region's countries such as the stage of economic development, the low shares of working age population to total population, as well as gender inequality. Policies that influence the access of low-income households and women to opportunities such as education and finance can also contribute to reducing inequality.

The rest of this paper is structured as follows. After a presentation of the stylized facts in section II, section III focuses on the impact of income and gender inequality on growth. Section IV presents empirical findings on the drivers of inequality. Section V summarizes the findings and concludes.

\section{DATA AND STYLIZED FACTS: TRENDS In INCOME AND GENDER INEQUALITIES}

Data on poverty and inequality. Poverty is from the World Bank's World Development Indicators database. Income inequality is measured by the net Gini (measured by the Gini coefficient after taking into account the effects of taxes and redistributive government programs). We make use of the latest data from the Standardized World Income Inequality Database (SWIID, Soltz 2014), which provides for the broadest country coverage over time by incorporating a number of data sources to maximize the comparability and coverage across countries over time. However, a disadvantage of this dataset is that missing observations are generated via model-based multiple imputation estimates. While the available data gives an indication of the trends across countries and regions, it should be interpreted carefully since household surveys in sub-Saharan Africa are less frequent and often not comparable. Nevertheless, the presented trends are broadly consistent with those using data of higher quality available for a smaller set of countries (see e.g. Beegle and others 2016). Gender inequality is measured by the United Nations' gender inequality index (GII). A composite index of gender inequality is useful because different gender gaps are often correlated and re-enforcing each other. The GII captures gender inequality in health (maternal mortality ratio and adolescent fertility rate), empowerment (gap in secondary education and share of parliamentary seats) and economic participation (gap in labor force participation rates). Gender-related legal restrictions are measured using an index that captures how laws and regulations constrain women's ability to participate in economic activity and entrepreneurial activity. The data on these restrictions are sourced from the World Bank's Women, Business and the Law Database.

\section{Sub-Saharan Africa's poverty rates and income inequality remain among the highest in the} world. While new estimates released by the World Bank report a decline in sub-Saharan Africa's poverty rates from 57 percent in 1990 to less than 43 percent in 2012, the poverty rates remain the highest in the world and the rapid rise in the population has led to an increase in the number of extreme poor (Beegle and others 2016). In addition, Sub-Saharan Africa has the second highest 
levels of income inequality, after Latin America and the Caribbean (Figure 1). ${ }^{2}$ Despite relatively high growth in recent years, overall, inequality appears to have remained broadly unchanged, although there is quite a bit of variation across countries (Bhorat and others 2015 and Beegle and others 2016). Countries such as Lesotho, Niger, and Sierra Leone experienced significant declines in income inequality. However, in one third of countries for which data is available, cumulative growth for individual countries over the period 1995-2011 were associated with increases in income inequality.

\section{Gender inequality also remains high in the region.}

Sub-Saharan Africa remains one of the regions with the highest gender inequality, just behind the Middle despite improvement arising from shrinking gender gaps in education, and improved health outcomes, and despite the fact that female labor force participation rates are on average the highest in the world. Similarly, despite some progress, sub-Saharan Africa continues to have more legal gender-based restrictions than comparator groups (Figure 3; Demirguc-Kunt and others 2013; Gonzales and others 2015a).

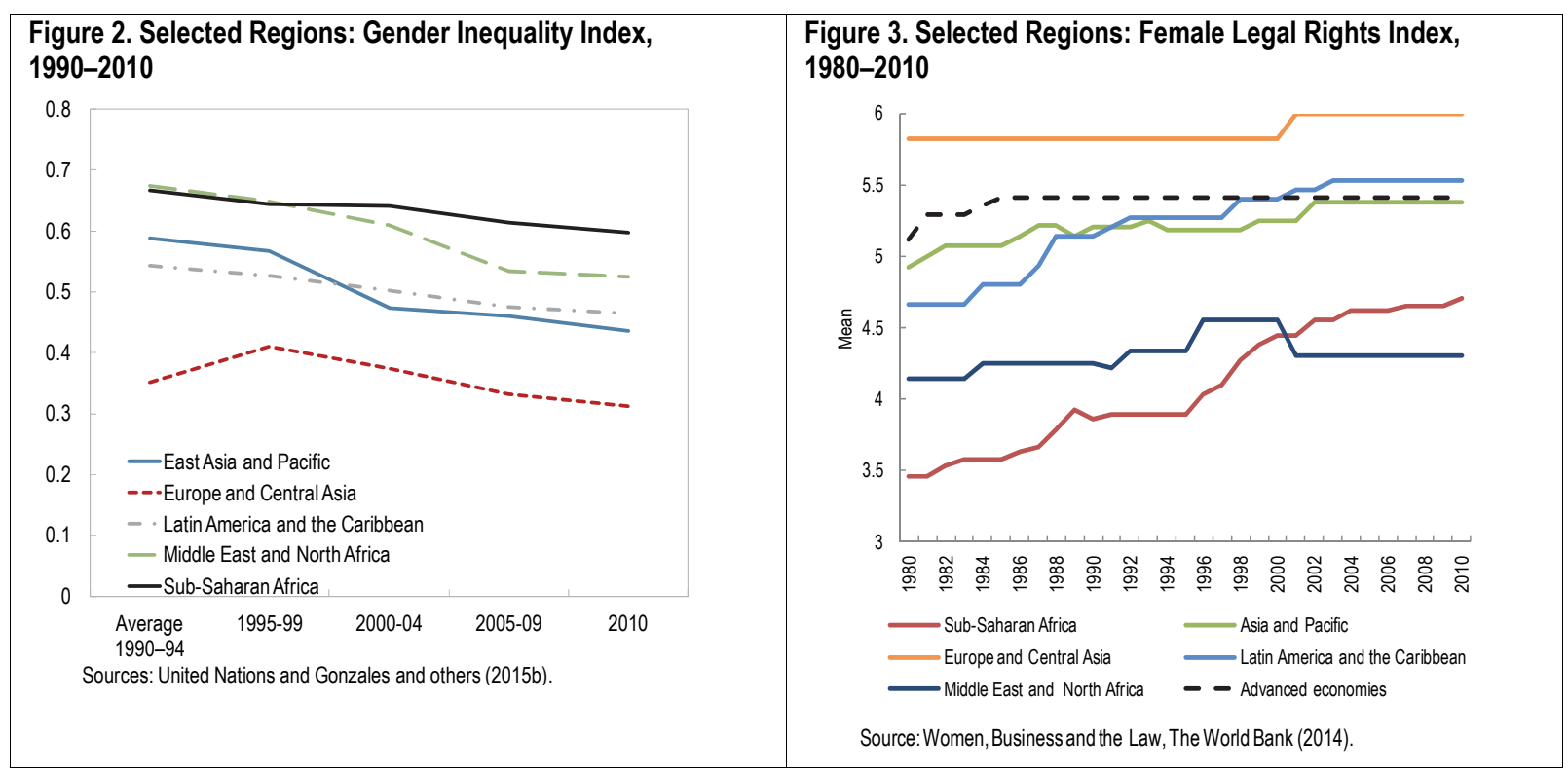

\footnotetext{
${ }^{2}$ The findings on the regional trends in inequality are broadly robust to the use of inequality estimates based on household survey data. Income inequality displayed for Latin America and the Caribbean is based on income measures which tend to exhibit higher levels of inequality than measures based on consumption. Sala-i-Martin (2002) shows that poverty and inequality increased in sub-Saharan Africa between 1970 and 1998.
} 
The high level of income inequality in the region begs the question why it remains high. Can this be explained by the generally lower level of economic development and/or by higher level of gender inequality? A preliminary analysis of the data suggests that factors well beyond these are actually at work:

- Consider the link between the development levels and income inequality (Figure 4). Kuznets (1955) famously hypothesized an inverse-U shaped relationship between the two variables with: low levels of inequality at earlier stages of development; an increase in inequality as countries industrialize and income increases rapidly; and declining inequality at higher income levels. Relative to the rest of the world, sub-Saharan Africa has markedly higher levels of income inequality at all stages of development. By comparison, the successful growth performance of ASEAN countries has been partly attributed to the lower initial levels of income inequality (Balakrishnan, Steinberg, and Syed 2013).

- Recent empirical work finds that gender inequality at the global level is an important source of income inequality, with gender gaps in education and health outcomes as the main drivers in emerging markets and low-income countries (Gonzales et al. 2015b). However, despite both types of inequalities being high in sub-Saharan Africa compared to other regions, the association between overall gender inequality and income inequality is much weaker in subSaharan Africa than elsewhere in the world (Figure 5). This points to other factors accounting for income inequality in the region and the paper aims to draw out some of these factors. ${ }^{3}$

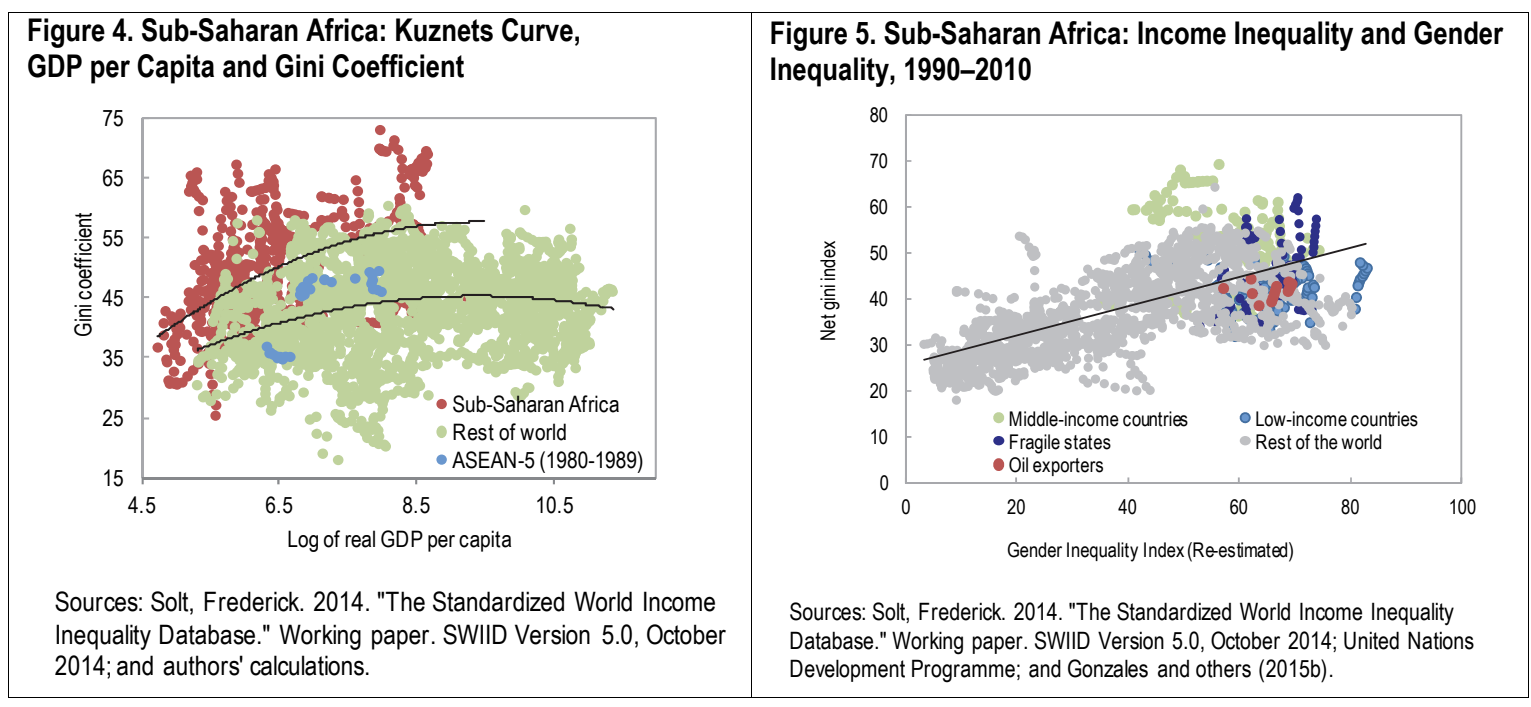

\footnotetext{
${ }^{3}$ It should be noted that the gap between male and female labor force participation rates is on average 15 percentage points lower in sub-Saharan Africa than in the rest of the world. This mainly reflects the generally low female labor force participation gaps in low-income and fragile economies where women have to work for subsistence, often in the low-productivity agricultural sector. At higher income levels, the gap increases as women may face the tradeoff between homemaking and joining the labor force. The poor ranking of low-income sub-Saharan African countries in terms of the GII in Figure 5 despite relatively low gender differences in labor force participation rates suggest that other aspects of gender inequality in education, health, and empowerment play a substantial role in these countries.
} 


\section{INEQUALITY AND GROWTH REVISITED}

\section{A. Selective Literature Review: Income Inequality and Growth}

There is growing evidence that income inequality hampers growth. Lower net income inequality has been robustly associated with faster growth and longer growth spells for a large number of advanced and developing countries (Berg and Ostry 2011; Ostry, Berg, and Tsangarides 2014). Similarly, increases in the income share of the poorest 10 percent have been associated with higher growth (Dabla-Norris and others 2015).

Various channels can lead to a negative association between income inequality and growth. With imperfect credit markets, low-income households' ability to invest in education and physical capital is impaired and limits income mobility (Galor and Zeira 1993; Corak 2013). High inequality can reduce private investment due to socio-political instability and poor governance. In contrast, inequality can spur growth by enabling rich households to invest more due to their higher marginal propensity to save or when inequality creates incentives for innovation and entrepreneurship, or differences in rates of returns to education may encourage more people to seek higher education (Cingano 2014).

Some of the channels through which the negative association between inequality and growth works may be stronger at lower levels of development. There is evidence suggesting that income inequality holds back growth in low-income countries (Barro 2000). Some of the channels noted above may have a stronger impact at early stages of development and become less binding as economies develop - for example, the extent of credit-constrained households and impact of imperfect credit markets, or the extent of poverty and resulting political implications of high inequality. Our analysis, therefore, distinguishes between countries at different stages of development when exploring the association between income inequality and economic growth.

Despite a large body of empirical work, there is no consensus on the link between income inequality and growth. The early consensus was that inequality could be either growth-promoting or growth-inhibiting depending on various factors (Barro 2000). The lack of robustness could be due to several factors. First, the effect of inequality on growth changes at different levels of development. Second, as overall income inequality is a composite measure reflecting inequality of opportunity and inequality of returns to effort, the effect of inequality on growth depends on the relative strength of each dimension. Third, it could be a reflection of different empirical methods that capture different time horizons. Fourth, income inequality measures may be reflecting other dimensions of inequality (such as gender inequality and inequality in education) that are important determinants of economic growth.

\section{B. Selective Literature Review: Gender Inequality and Growth}

Gender inequality can be assessed by gaps in opportunities (education, legal system, access to finance) as well as outcomes (employment and political empowerment). It is not always possible to get the gender dimensions of inequality from aggregated data. In calculating survey-based income inequality indicators, it is often assumed that all incomes are shared equally within 
households. However, plenty of anecdotal evidence suggests this is not always the case-e.g., schooling expenses for boys and girls, differential access to financial services and bank accounts.

Differential access to opportunities is a major source of gender inequality. Despite considerable progress toward achieving gender parity in access to education, significant gender gaps remain. Education inequality affects the average quality of human capital and reduces growth (Klasen 1999). Female education contributes to improvements in children's health, reductions in fertility rates and increases in labor force participation rates, and better quality of human capital of future generations (Mitra, Bang, and Biswas 2015). Restrictions on women's rights to inheritance and property, as well as legal impediments to undertaking economic activities are strongly associated with larger gender gaps in labor force participation (Gonzales and others 2015a).

Overall, gender gaps in economic participation have been shown to result in large GDP losses across countries of all income levels (Elborgh-Woytek and others 2013; Stotsky 2006). These losses result from a less efficient allocation of resources due to a restricted talent pool (Cuberes and Teigner 2015; Esteve-Volart 2004). Mitra, Bang, and Biswas (2015) report that that greater presence of women in legislative bodies may alter the composition of public expenditure in favor of health and education, which can raise potential growth over the medium to long run.

However, the contribution of various gender gaps to growth, especially after controlling for income inequality, has been less understood. Most studies examine the effects of different dimensions of gender inequality in separate regressions (Klasen and Lamanna 2009; ElborghWoytek and others, 2013). A few who explored the association between growth and a variety of gender gaps (e.g., Mitra, Bang, and Biswas 2015, Amin, Kuntchev, and Schmidt 2015), did not explore the possibility that income inequality could also capture other dimensions (such as the rural-urban income divide) that impact economic growth.

\section{Empirical Methodology and Data}

We examine whether the persistently high levels of gender and income inequality had a bearing on the region's growth performance. An econometric analysis is conducted relating growth in GDP per capita in a sample of 115 countries to indicators of income and gender inequality as well as commonly-used growth determinants. ${ }^{4}$ The latter include variables such as initial income - as lower levels tend to be associated with higher growth as countries catch up - the initial level of infrastructure, years of schooling, and investment to GDP - capturing the quality of the capital and the labor force - inflation and indicators of institutional quality - proxying the quality of macroeconomic and political management - and terms-of-trade changes to reflect external shocks. Appendix Table 1 provides exact definitions of the variables and data sources used. Appendix 1 also provides information on the coverage of the countries. Due to the paucity of data across inequality measures and various growth determinants, the country coverage varies between models.

\footnotetext{
${ }^{4}$ This paper uses the World Bank's classification of countries. However, the group of low-income countries includes lower-middle income countries, given their many similarities.
} 
The lack of good-quality and comparable measures of income inequality across countries is an obstacle in exploring the growth-inequality nexus. Hence, the analysis in this paper is based on income inequality, measured by multiple indicators and from various data sources - including the Gini coefficient and ratios of the earnings share of the top vs. the bottom of the income distribution. Specifically, the regressions were estimated using three alternative measures of income inequality, all consistently indicating that inequality remains high in sub-Saharan Africa and Latin America. For all variables, we consider each five-year period, with the initial value representing the observation in the first year or, if unavailable, the latest available observation in the previous period.

- Initial income inequality is the net Gini and is taken from the SWIID v.5.0. The empirical results are broadly similar if the traditional (market) Gini is used.

- Initial ratio of the top 20 to the bottom 40 percentiles of the income distribution is an alternative measure of inequality, related to the Palma index of inequality. This measure of inequality gives more prominence to income distribution at the top 20 percent of the population relative to that of the bottom 40 percent of population. The source of the data is the World Bank's World Development Indicators (WDI) database, and is supplemented by the UNU-WIDER database.

- Initial income share of middle class is calculated by the sum of income shares of the third and fourth quintiles of population. Data sources are the same as the ones for the variable "initial ratio of the top 20 to the bottom 40 percentile of income distribution."

Gender inequality is primarily captured by the UN's Gender Inequality Index (GII), which combines various gender gaps in opportunities and outcomes into a single index. However, the UNDP published this index for a few cross-sections (2006 and after). We use an extended GII for the period 1990-2010 which was constructed using the GII methodology obtained from Gonzales and others (2015b). The GII ranges between 0 (equal) and 100 (unequal) and is averaged over each five year period.

There are considerable legal restrictions on women's participation in economic activities, but the GII does not capture these restrictions. Therefore, in addition to the GII, our analysis includes an index of gender-related legal conditions. A Female legal inequity index is constructed as the sum of six legal indicators (in 0-1 format) representing women's legal rights to earn and hold income and wealth. The index ranges between 0 and 6 , with higher values corresponding to less equitable legal rights for women. The six indicators included are: (a) unmarried women have equal property rights for immovable property; (b) married women have equal inheritance rights; (c) joint titling of property is default for married couples; (d) married women can get a job or pursue a profession; (e) adult married woman can open a bank account; and (f) married woman can sign contracts (without permission from another family member). It should be noted that the measures of income inequality capture inequality at the household level. The gender inequality index, on the other hand, captures a combination of intra- and inter-household inequality to the extent that women are a member of a household or that they head a household. 
Key considerations in the empirical strategy were to include as many sub-Saharan African countries in the sample and address endogeneity concerns. Given data availability, the regressions were estimated for the 1995-2014 period and rely on non-overlapping five-year averages to abstract from business cycle fluctuations in growth rates and deal with data gaps in certain years (e.g., in the education and inequality measures). To account for possible endogeneity of the inequality and investment variables, the estimations use two-step system generalized methods of moments (system-GMM) and initial levels of inequality for each 5-year period.

\section{While system-GMM is a suitable approach for the analysis in this paper, the model} specification and selection of appropriate control variables is critical to obtaining sensible and robust estimates. We use various specification tests to ensure that the assumptions of no secondorder serial correlation in the errors and that of the validity of the instruments hold. To show no second-order serial correlation, we use the Arellano-Bond test statistic, which fails to reject the null hypothesis of zero correlation. Moreover, since the Arellano-Bond (system GMM) estimators generate large numbers of instruments, this can lead to over-identification. To see whether this is a concern, we applied the Hansen J statistic to test for over-identification. In our model specifications, this statistic passes the criteria for no over-identification problem, leading us to conclude that the problem of excessive instruments is not too serious in our specification. ${ }^{5}$

\section{General Results}

Our empirical findings are based on a panel analysis of the relation between inequality and growth. Using a reduced-form relationship between inequality and growth, we start with a simple Solow growth model with added inequality indicators (Table 1). Before reporting on a more complete growth model, this section begins by focusing on various dimensions of inequality in simplified models. These models control for initial income, initial level of infrastructure, and an indicator of institutional quality, as well as individual indicators approximating various inequalities (Table 1). Income inequality is measured by three different indicators: the most commonly used Gini coefficient based on net incomes, share of income going to middle-class, or the relative gap between the richest quintile's income shares to the shares of the poorest 40 percent of the population. Other disparities covered are gender inequality index (covering both opportunities and outcomes) and an index of legal restrictions on women's participation in economic activities.

\footnotetext{
${ }^{5}$ The Xtabond2 package for STATA (Roodman 2009) is used to estimate the system-GMM regressions.
} 
Table 1. Growth, Inequality and Gender Inequality: System GMM Results from Baseline Model ${ }^{1}$

\begin{tabular}{|c|c|c|c|c|c|}
\hline All Countries & (1) & $(2)$ & (3) & $(4)$ & $(5)$ \\
\hline Initial income per capita (log) & $-1.420^{* * *}$ & $-1.728^{* * *}$ & $-0.998^{\star * *}$ & $-1.921^{* * *}$ & $-1.209^{* * *}$ \\
\hline Initial level of infrastructure & $0.597^{* * *}$ & $0.622^{* * *}$ & $0.646^{* * *}$ & $0.372^{* *}$ & $0.539^{* * *}$ \\
\hline Institutional quality (index) & $0.046^{* *}$ & $0.054^{* *}$ & 0.022 & $0.064^{* * *}$ & $0.054^{* *}$ \\
\hline \multicolumn{6}{|l|}{ Measures of Inequality } \\
\hline Initial income inequality(t20/b40 ratio) & -0.060 & & & & \\
\hline Initial income inequality (t20/b40 ratio) x LICs & $-0.354^{* * *}$ & & & & \\
\hline Initial income inequality (net Gini) & & -0.025 & & & \\
\hline Initial income inequality (net Gini) x LICs & & $-0.048^{* * *}$ & & & \\
\hline Initial income share of middle class & & & $0.158^{* * *}$ & & \\
\hline Gender inequality (lagged) & & & & $-0.031^{* *}$ & \\
\hline Gender inequality x LICs (lagged) & & & & $-0.039^{* * *}$ & \\
\hline Female legal inequity (index) & & & & & -0.246 \\
\hline Constant & $6.470 * * *$ & $9.310^{* * *}$ & -1.652 & $12.879^{* * *}$ & $2.664^{*}$ \\
\hline Serial correlation ( $p$-value) & 0.103 & 0.044 & 0.370 & 0.121 & 0.907 \\
\hline Hansen test ( $p$-value) & 0.259 & 0.230 & 0.493 & 0.943 & 0.553 \\
\hline Observations & 381 & 429 & 269 & 430 & 334 \\
\hline Number of countries & 121 & 117 & 114 & 115 & 84 \\
\hline Emerging and Developing Countries & (6) & $(7)$ & $(8)$ & (9) & $(10)$ \\
\hline Initial income per capita (log) & $-1.133^{* * *}$ & $-1.382^{\star * *}$ & $-0.843^{\star * *}$ & $-1.615^{\star * *}$ & $-1.201^{* * *}$ \\
\hline Initial level of infrastructure & $0.586^{* * *}$ & $0.618^{* * *}$ & $0.563^{* * *}$ & $0.365^{*}$ & $0.574^{* * *}$ \\
\hline Institutional quality (index) & 0.027 & 0.035 & 0.012 & $0.045^{* *}$ & 0.045 \\
\hline \multicolumn{6}{|l|}{ Measures of Inequality } \\
\hline Initial income inequality (t20/b40 ratio) & $-0.116^{* *}$ & & & & \\
\hline Initial income inequality (t20/b40 ratio) x LICs & $-0.260^{* * *}$ & & & & \\
\hline Initial income inequality (net Gini) & & -0.038 & & & \\
\hline Initial income inequality (net Gini) x LICs & & $-0.036^{* *}$ & & & \\
\hline Initial income share of middle class & & & $0.154^{* * *}$ & & \\
\hline Gender inequality (lagged) & & & & $-0.057^{* * *}$ & \\
\hline Gender inequality x LICs (lagged) & & & & $-0.024^{* *}$ & \\
\hline Female legal inequity (index) & & & & & -0.279 \\
\hline Constant & $5.677^{* * *}$ & $8.293^{* * *}$ & -1.484 & $12.667^{* * *}$ & 2.770 \\
\hline Serial correlation ( $p$-value) & 0.246 & 0.076 & 0.400 & 0.141 & 0.922 \\
\hline Hansen test ( $p$-value) & 0.677 & 0.187 & 0.588 & 0.904 & 0.625 \\
\hline Observations & 268 & 300 & 234 & 301 & 266 \\
\hline Number of countries & 87 & 84 & 85 & 81 & 67 \\
\hline
\end{tabular}

Source: Authors' calculations.

The symbol ${ }^{*}{ }^{* *}$, and ${ }^{* *}$ indicate that the estimated coefficient is statistically significantly different from zero at the 10,5 , and 1 percent level, respectively.

1. The dependent variable is real GDP per capita growth, averaged over non-overlapping 5-year periods, for 1995-2014. See footnotes in Table 2 and Appendix 1 for definitions of other variables. LICs group include countries classified as low-income and lower middleincome groups by the World Bank.

\section{CInternational Monetary Fund. Not for Redistribution}


Inequality impedes growth. A robust negative association is present between average real GDP per capita growth and initial income distribution. However, this negative association between initial inequality and subsequent growth holds primarily for countries at early stages of developments. The results suggest high income inequality impedes growth in countries where credit constraints and credit market imperfections are likely to be more common, which limit low-income households' ability to invest in physical as well as human capital and to mitigate against shocks. These findings are consistent with previous studies, which find the relationship between growth and inequality negative below a certain threshold of income per capita (see Neves and Silva 2014). The negative association between countries' average growth rates and their income distribution at the beginning of 5-year periods is robust to different measures of income inequality. To further assess robustness, the models were re-estimated after dropping developed countries and the results were broadly unchanged (see bottom panel of Table1). A clear negative relationship is present between real GDP per capita growth and gender inequality.

The observed negative association between growth and inequality in low-income countries is robust to the inclusion of other variables. In addition to assessing the robustness of various inequality indicators and country samples, the robustness of the growth-inequality link is examined by extending the model to incorporate other commonly used covariates of growth (Table 2) beyond the three factors already reported in Table 1 . Based on recent studies on growth empirics, better macroeconomic management (proxied by inflation), less external shocks (measured as percent change in terms of trade), dependent population growth, and schooling are often considered determinants of economic growth. Adding these variables into the growth-inequality model mostly reconfirms the results on inequality and growth. These broader growth models are estimated using the whole sample while possible non-linearity of the relationship between growth and inequality is captured through an interaction term for low-income countries. This approach allows keeping the sample as broad as possible.

\section{The main results in Table 2 are as follows:}

- Income inequality is robustly related to lower growth in low-income countries, irrespective of the measure of income inequality. ${ }^{6}$ The negative association between growth and income inequality among low-income countries is robust to the measure of inequality, proxied by the Gini coefficient, the income gap between the top 20 percent and the 40 percent poorest segment of the population, or the income share of the middle class (as proxied by the 40 to 80 percentiles of population in the income distribution), as shown in Models 1 to 3 of Table 2. For example, a one-percentage point reduction in the initial Gini coefficient in low-income countries is associated with a 0.15 percentage point cumulative increase in growth over a 5-year period.

\footnotetext{
${ }^{6}$ The analysis uses interaction terms to capture non-linearity in the inequality-growth relationship. However, the estimated effects of the income and gender inequality variables are broadly robust to limiting the sample only to developing countries and to reducing the number of control variables. The finding of significant effects of income and gender inequality after controlling for variables that may be interrelated with the inequality variables is consistent with Berg and Ostry (2011) and Ostry and others (2014).
} 
- Growth is also negatively associated with the multidimensional index of gender inequality in low-income countries and with gender-related legal restrictions for all countries. As shown in Models 4 to 6 of Table 2, a one percentage point reduction in gender inequality in low-income countries is associated with higher cumulative growth over 5 years of 0.2 percentage points in low-income countries, a result in line with previous estimates (Amin, Kuntchev, and Schmidt 2015). ${ }^{7}$ The adverse effect of legal barriers appears to be independent of the countries' stage of development as the coefficient remains significant for all countries even when the interaction term for low-income countries is included. This suggests that legal barriers to women's participation in economic activities during the examined period were a more binding constraint on women's economic activities in advanced countries than those related to political empowerment, education gaps, health gaps (fertility and female mortality rates) and employment gaps (labor force participation rates). This could be the case, for example, if women have access to education or health care, but legal barriers constrain the type of activities that they are able to engage in and the opportunities that are available to them.

- The findings suggest that gender inequality, including from legal restrictions, impacts growth through other channels than income inequality. Adding gender inequality variables did not diminish the association between income inequality and growth. Hence, gender inequality impacts growth through other channels. For example, higher gender inequality may adversely impact gender gaps in educational attainment. Similarly, other aspects of household income inequality that are unrelated to gender inequality may be affecting growth in low-income countries such as the rural-urban income inequality or inequality arising from a countries' dependence on natural resources exports whose revenues are appropriated by a few individuals.

\footnotetext{
${ }^{7}$ Many studies rightly note the significance of the value added to the economy by women from family-related activities, which are not measured in GDP.
} 
Table 2. Growth, Inequality and Gender Inequality: GMM Results from Extended Model ${ }^{1}$

\begin{tabular}{|c|c|c|c|c|c|c|}
\hline & (1) & $(2)$ & (3) & (4) & (5) & (6) \\
\hline \multicolumn{7}{|l|}{ Measures of Inequality } \\
\hline Initial top 20 to bottom 40 income ratio & 0.006 & & & & & $-0.188^{* * *}$ \\
\hline Inifial top 20 to bottom 40 income ratio $x$ LICs & $-0.207^{* * *}$ & & & & & \\
\hline Initial income inequality (net Gini) & & -0.009 & & & & \\
\hline Initial income inequality (net Gini) x LICs & & $-0.030 * * *$ & & & & \\
\hline Initial income share of middle class ${ }^{2}$ & & & $0.081 * *$ & & & \\
\hline Gender inequality (lagged) & & & & -0.017 & & 0.005 \\
\hline Gender inequality x LICs (lagged) & & & & $-0.029 * * *$ & & -0.020 ** \\
\hline Female legal inequity (index) & & & & & $-0.326 * *$ & -0.296 ** \\
\hline Female legal inequity (index) $x$ LICs & & & & & 0.185 & \\
\hline \multicolumn{7}{|l|}{ Other control variables } \\
\hline Initial income per capita (log) & $-1.234 * * *$ & $-1.347^{* * *}$ & $-1.081 * * *$ & $-1.746 * * *$ & $-1.148 * * *$ & $-1.608^{* * *}$ \\
\hline Fixed capital investment (\% GDP) & 0.134 * & $0.184^{* * *}$ & -0.014 & 0.093 * & 0.132 * & 0.028 \\
\hline Schooling (years) & 0.119 & 0.068 & $0.159 *$ & 0.045 & 0.105 & $0.154 *$ \\
\hline Dependent population growth (\%) & $-0.356 * *$ & $-0.293 * *$ & $-0.539 * * *$ & -0.224 & $-0.306 * *$ & $-0.286 * *$ \\
\hline Infrastructure index & $0.238 *$ & 0.194 & $0.270 *$ & $0.294 *$ & 0.237 & $0.334 * *$ \\
\hline High inflation dummy & $-1.583 * * *$ & $-1.627^{* * *}$ & $-1.621 * * *$ & $-1.228 * * *$ & $-1.472 * * *$ & $-1.552^{* * *}$ \\
\hline Terms of trade (percent change) & $0.068 * *$ & $0.076 * * *$ & $0.091 * * *$ & $0.098 * * *$ & $0.063 * *$ & $0.094^{* * *}$ \\
\hline Institutional quality (index) & $0.047^{* * *}$ & $0.063 * * *$ & $0.040 * *$ & $0.080^{* * *}$ & $0.064^{* * *}$ & $0.054^{* * *}$ \\
\hline Constant & $4.117^{*}$ & $4.087^{* *}$ & 3.171 & $7.889 * *$ & 2.112 & 6.840 \\
\hline Number of instruments & 15 & 15 & 14 & 15 & 15 & 17 \\
\hline Serial correlation ( $p$-value) & 0.071 & 0.025 & 0.202 & 0.209 & 0.154 & 0.274 \\
\hline Hansen test (p-value) & 0.210 & 0.335 & 0.319 & 0.445 & 0.712 & 0.700 \\
\hline Country fixed effects & Yes & Yes & Yes & Yes & Yes & Yes \\
\hline Time (period) fixed effects & Yes & Yes & Yes & Yes & Yes & Yes \\
\hline Observations & 344 & 384 & 237 & 419 & 304 & 240 \\
\hline Number of countries & 110 & 106 & 104 & 115 & 78 & 78 \\
\hline
\end{tabular}

Source: Authors' calcualtions.

The symbol *, **, and ${ }^{* *}$ indicate that the estimated coefficient is statistically significantly different from zero at the 10,5 , and 1 percent level, respectively.

${ }^{1}$ The dependent variable is real GDP per capita growth, averaged over non-overlapping 5-year periods, for 1995-2014. LICs group includes countries classified as low-income and lower-middle income countries by the World Bank. The regressions are estimated using the robust two-step system GMM estimator and include country and period effects. The $p$-values of the tests of second-order serial correlation and the Hansen test of overidentifying restrictions are reported. See Appendix Table 1 for exact definitions of variables and sources of data reported.

${ }^{2}$ Income share of middle class is percent share of income attributed to third and fourth quintiles of population. 


\section{E. Implications for sub-Saharan Africa}

\section{A growth decomposition analysis suggests that addressing high inequality could significantly affect growth in sub-Saharan Africa (Figure 6). Compared to a sub-group of ASEAN countries} (Indonesia, Malaysia, Philippines, Thailand and Vietnam) that have a strong track record in terms of growth, sub-Saharan Africa's average annual real GDP per capita growth has been about $1 \frac{1}{2}$ percentage points lower respectively over the last decade. Weaker infrastructure, lower levels of investment in fixed and human capital, higher dependency ratios, and lower quality of institutions were key factors explaining this growth shortfall. But the contribution of inequality is also substantial. More precisely, reducing the three inequality indicators to the level currently observed in ASEAN countries could boost the region's annual per capita GDP growth by on average about 0.9 of a percentage point, roughly the same order of magnitude as the impact on annual per capita growth from closing the infrastructure gap between the two regions. ${ }^{8}$ Moreover, compared with Latin America and the Caribbean which has a growth differential with ASEAN of a similar order of magnitude as sub-Saharan Africa, the growth effects from reducing gender inequality and legal gender-related restrictions are sizeable for sub-Saharan Africa. Notwithstanding its higher levels of income per capita relative to ASEAN, income inequality is found to be a key factor holding back growth in the Latin America and the Caribbean. This is not surprising given that Latin America and the Caribbean stands out as the region with the highest levels of income inequality.

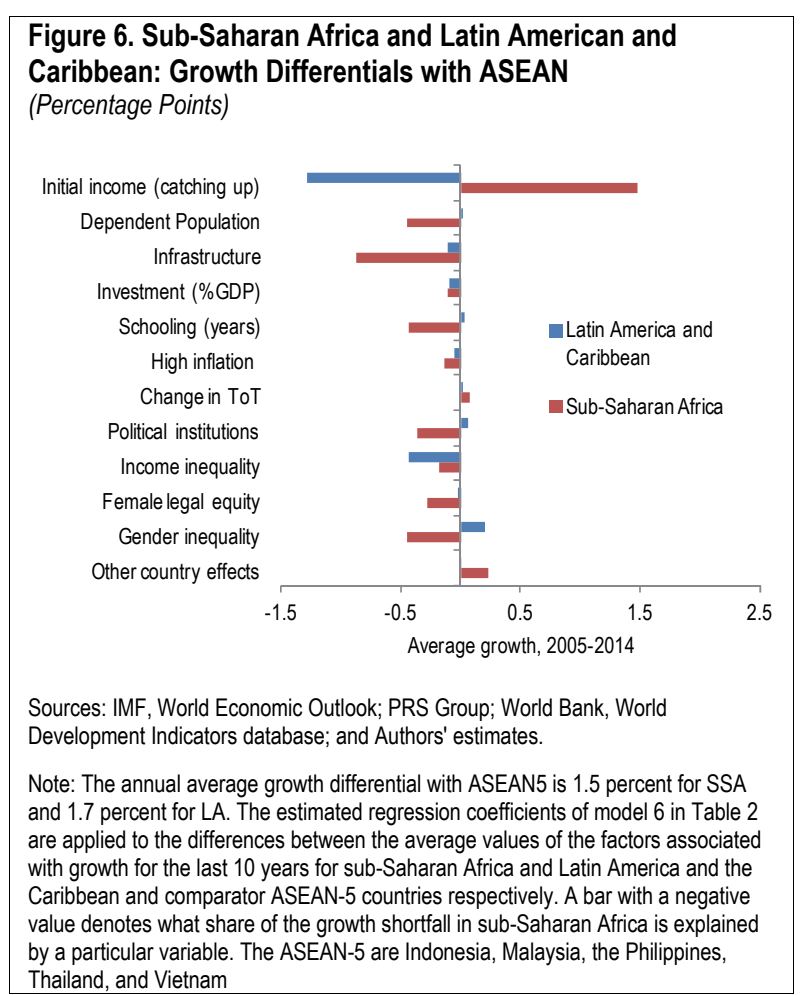

\footnotetext{
${ }^{8}$ The next section of the paper finds per capita GDP growth to have been associated with contemporaneous increases in income inequality for sub-Saharan African countries. The findings in this section are based on regressions techniques that address possible endogeneity and account for a common set of control variables that could be associated with higher growth and increases in income inequality.
} 
The impact of income and gender inequality on growth varies across subgroups in subSaharan Africa (Figure 7). Using the same approach as for the whole region, the growth decomposition analysis for the subgroups yields the following additional lessons:

- In low-income countries (excluding fragile states) the catch-up effect from a low initial income relative to the ASEAN countries contributes about $2 \frac{1}{2}$ percentage points of real GDP per capita growth. However, this catch-up effect is more than undone by weak infrastructure and lower human capital accumulation. Gender inequality accounts for $3 / 4$ percentage points of the growth differential.

- For fragile states, the lower quality of infrastructure and political institutions explains the largest fraction of the growth differential. Reducing gender inequality could boost annual per capita GDP growth by $2 / 3$ percentage points, while the potential effects of a reduction in income inequality and legal gender-based restrictions are smaller.

- For middle-income countries - where infrastructure and educational attainment gaps tend to be smaller-and oil-exporting countries reducing income inequality to the levels observed in ASEAN countries is an important factor to raise growth. The growth payoff from removing legal gender-related restrictions also appears particularly strong for oil-exporting sub-Saharan African countries. ${ }^{9}$

Having shown that inequality, both income and gender, impede growth — with low-income countries most affected - we next turn to understanding some of the drivers of income inequality.

\footnotetext{
${ }^{9}$ The finding that the removal of gender-related restrictions affects growth positively in the oil exporting countries may reflect correlation rather than causation given that oil exporting countries can, if conditions are right, grow without much labor effort as oil and minerals are capital intensive. This would be the case if gender equality is correlated with other conditions, such as better property rights, or a greater integration with developed-country capital markets, that make it easier for foreign companies to exploit mineral reserves.
} 
Figure 7. Subgroups of Sub-Saharan Africa: Growth Differential with ASEAN Countries (Percentage Points)
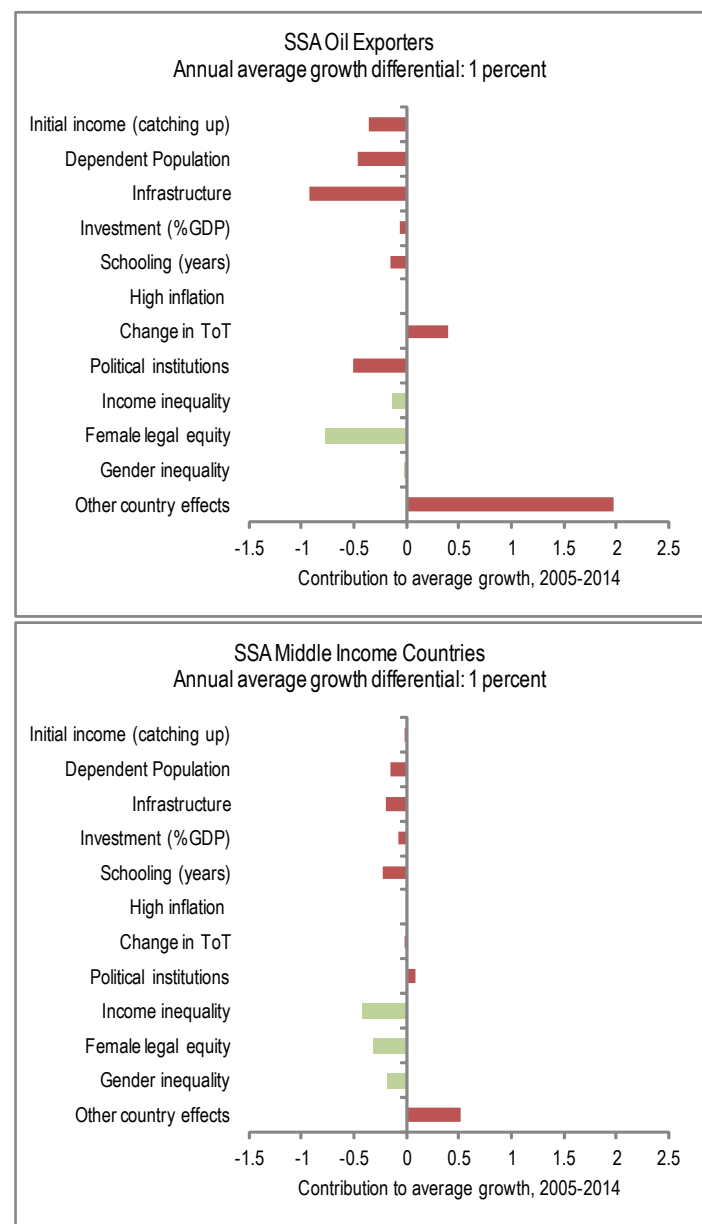
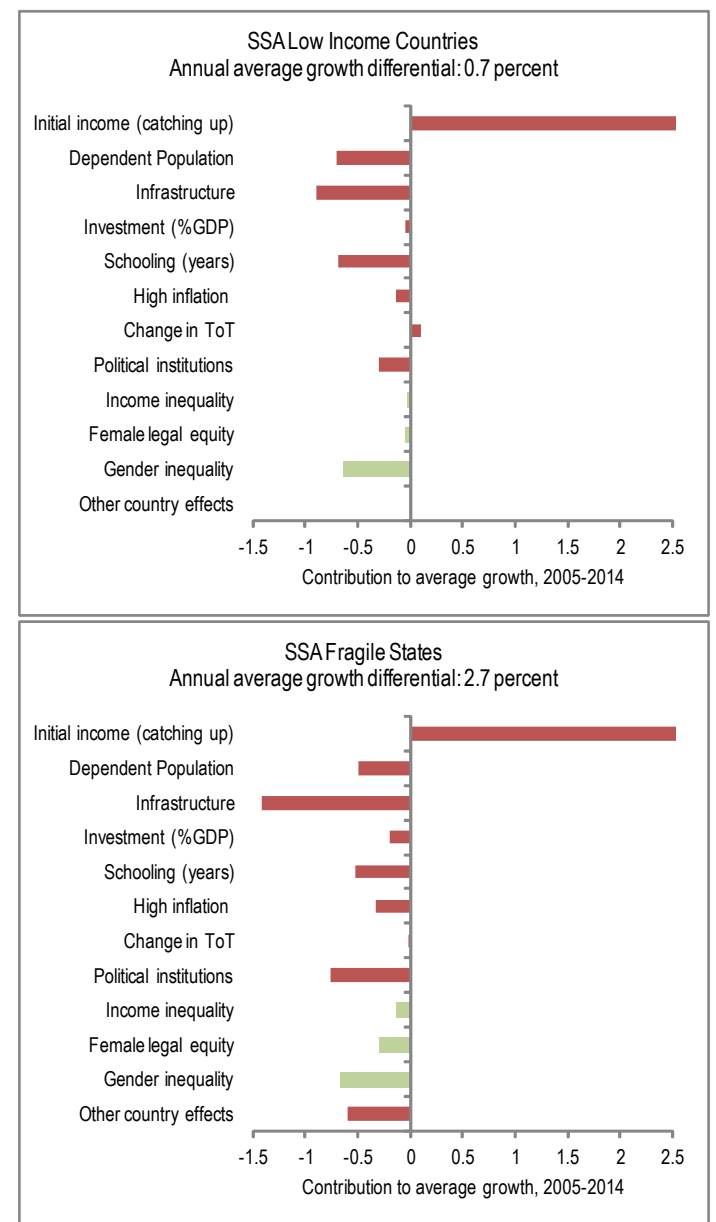

Source: IMF World Economic Outlook database; PRS Group; World Development Indicators database; and Authors' estimates.

Note: The estimated regression coefficients of model 6 in Table 2 are applied to the differences between the average values of the factors associated with growth for the last 10 years for sub-Saharan Africa and comparator ASEAN-5 countries. Green bars represent the three inequality indictators included in the regression. A bar with a negative value denotes what share of the growth shortfall in sub-Saharan Africa is explained by a particular variable. The ASEAN-5 are Indonesia, Malaysia, the Philippines, Thailand, and Vietnam.

\section{WHAT DRIVES INCOME INEQUALITY?}

\section{A. A Brief Literature Review}

What are the factors driving income inequality? The empirical literature has examined the relationship between a wide range of factors and income inequality. Both the initial level of income and inequality have been considered in the literature, although their impact is found to be ambiguous. Previous empirical work testing the Kuznets inverse-U hypothesis that inequality initially increases and then declines with countries' level of economic development has yielded mixed results (Barro 2000 and 2009). Likewise, the effect of real GDP growth is ambiguous - in the context of a structural transformation, inequality may deteriorate with increased growth. Similarly, the effect of initial inequality on change in inequality appears ambiguous. In "inequality traps", high initial inequality can exacerbate inequality in the absence of policy measures. By contrast, "inequality convergence toward medium levels" can also imply that higher initial inequality gives 
rise to a reduction in inequality (Ravallion 2001). On the other hand, recent work has shown that more gender inequality reduces the ability of one segment of the economy to fully contribute to growth, development and results in a more unequal income distribution (Elborgh-Woytek and others 2013, Gonzales and others 2015b). The relationship between education inequality and income inequality is also ambiguous. Lower education inequality could theoretically lead to lower income inequality because education impacts access to jobs and opportunities. Recent empirical evidence suggests, however, that the correlation may be low if there is increasing returns to education and exogenous factors such as skill-biased technological progress that increase wages for those at higher levels of the income distribution (Castelló-Climent and Doménech 2014).

\section{Structural features such as demographics and the composition of GDP can also impact on income inequality. A faster demographic transition can contribute to reducing inequality by} reducing the number of dependent children, particularly for low-income households and allowing for greater female labor force participation and investment in human capital, adding benefits beyond the "demographic dividend" (Soares 2005; Soares and Falcao 2008). A higher share of the agricultural sector has been associated with lower poverty and inequality in sub-Saharan Africa (Christiansen, Demery and Kuhl 2007). On the other hand, exploitation of natural resources can lead to a more unequal income distribution, particularly if they are directly exported instead of representing an intermediate good (Buccellato and Alessandrini 2009).

Economic policies, either directly (e.g., fiscal redistribution) or indirectly (e.g., promoting financial inclusion), can impact income inequality. Fiscal redistribution can reduce inequality, particularly if it is progressive, targeted and well implemented (Ostry, Berg, Tsangarides 2014). The impact of education spending, used as a proxy for human capital, is ambiguous (Dabla-Norris and others 2015). If access is an issue, spending to improve coverage and quality of delivery, can foster equality of opportunity and reduce the skills premium. Financial development can contribute to a worsening of inequality in the presence of financial frictions, causing mostly the rich to have access to financial services (Greenwood and Jovanovic 1990). However, easing financial constraints can help reduce income inequality (Dabla-Norris and others 2015). Regional disparities in infrastructure provision can lead to higher spatial inequality and a worsening urban-rural divide. Access to water and electricity impact inequality as well by reducing the time devoted to accessing water supplies and increasing the opportunities for inclusion, particularly by allowing women to start household enterprises (WDR 2012). The impact of trade openness on inequality can go both ways, depending on the extent of trade creation and trade diversion (Dabla-Norris and others 2015). In many low-income countries, the transfer of low-skilled operations from advanced economies (outsourcing) can create opportunities in the manufacturing and services sector, but the overall impact on inequality depends on the extent of the shift from the informal to the formal sector, as well as the wage disparities. Similarly, the closure of industries due to cheaper imports can worsen income inequality.

\section{B. Empirical Strategy}

We undertake a systematic analysis of a range of structural and policy determinants of inequality using quantile regression in a sample of 135 countries between 1991 and 2010. Quantile regressions are used as their estimates are more efficient than those focusing on the mean, including binary models. This also allows for investigating the drivers of both increases and 
decreases in inequality. The sample includes 469 observations of non-overlapping 5-yearly changes in inequality. To disentangle the factors specific to low-income countries and sub-Saharan Africa and to account for the income dimension under high collinearity, interaction terms are included.

The analysis assesses if changes in inequality can be explained by various characteristics of the economy and policies that have been previously identified in the literature. These include demographic factors, other dimensions of inequality (gender and education inequality), dependence on trade in natural resources, fiscal policy variables, including the extent of redistribution and government education spending, and other macroeconomic determinants. The proxy for financial inclusion is a dummy variable reflecting the ability of women to open bank accounts. Capital stocks are used as proxies for cumulative government and private sector investment. These variables capture infrastructure gaps that remain high in sub-Saharan Africa. The definitions and constructions of the variables used in the regressions are in Appendix Table 2. The countries included in the empirical analysis are in Appendix 1.

The exercise is intended to provide broad evidence on the factors that are associated with changes in inequality rather than to articulate channels through which various factors affect income inequality. This is because many of the variables are endogenous with well-developed theories of reverse causality, e.g. from inequality to human capital accumulation. The analysis for the most part relies on relating five-year changes in inequality to beginning-of-period values of drivers of inequality to mitigate possible reverse causality. The only exceptions are real GDP per capita growth and the share of exports in natural resources which cover the contemporaneous five-year period. Given the interrelations between various policy and structural measures, the relationship of each variable to changes in income inequality is examined in a separate regression. The regressions control for the effect of initial income inequality.

\section{General Results}

Among the wide range of factors analyzed, and in line with the literature, the following appear to be positively associated with reducing inequality: GDP per capita growth, private capital stock, education spending, the share of the working age population, and fiscal redistribution, measured as the difference between market and net Gini-which can be considered an exogenous variable relative to the subsequent reduction in net inequality (Table 3). On the other hand, higher beginning-of-period gender and education inequality tends to increase net income inequality. The results support the existence of a convergence effect whereby countries starting at a higher level of inequality tend to experience larger reductions in income inequality. ${ }^{10}$

\footnotetext{
${ }^{10}$ The effect of the initial level of income per capita on changes in inequality is not statistically significant (not reported here). There is a high degree of multicollinearity between the initial level of inequality and GDP per capita.
} 
Table 3. Various Regressions of Determinants of Change in Inequality (Net Gini) ${ }^{1}$

\begin{tabular}{|c|c|c|c|c|c|c|}
\hline & \multicolumn{3}{|c|}{ Overall Sample } & \multicolumn{3}{|c|}{ 10th Percentile } \\
\hline & \multicolumn{3}{|l|}{ Explanatory } & \multicolumn{3}{|l|}{ Explanatory } \\
\hline & Variable (EV) & $\mathrm{EV}^{*} \mathrm{LIC}$ & $E V^{*} S S A$ & Variable (EV) & $E V^{*} \mathrm{LIC}$ & $E V^{*} S S A$ \\
\hline \multicolumn{7}{|l|}{ Growth: } \\
\hline GDP per capita growth & $-0.1010^{\star * *}$ & 0.0994 & & -0.0221 & $0.3490^{\star *}$ & \\
\hline GDP per capita growth & $-0.0991^{* * *}$ & & $0.3500^{* * *}$ & -0.0216 & & $0.3350^{* *}$ \\
\hline \multicolumn{7}{|l|}{ Structural factors: } \\
\hline Share of agriculture & $0.0515^{* * *}$ & $-0.0544^{* * *}$ & & $-0.0508^{* *}$ & -0.0054 & \\
\hline Share of working age pop. & $-0.0585^{\star}$ & -0.0084 & & -0.0159 & $-0.0423^{* *}$ & \\
\hline Education inequality & 0.0168 & -0.0113 & & 0.0048 & -0.0223 & \\
\hline Education inequality & $0.0240^{* *}$ & & $-0.0349^{* * *}$ & 0.0061 & & -0.0110 \\
\hline Gender inequality index & $0.0301^{* *}$ & $-0.0150^{*}$ & & 0.0044 & -0.0176 & \\
\hline Gender inequality index & $0.0308^{* * *}$ & & $-0.0251^{* * *}$ & 0.0013 & & -0.0160 \\
\hline Women's right to open bank account (dummy) & $1.3330^{*}$ & -0.0213 & & -1.2360 & $-2.2810^{*}$ & \\
\hline Women's right to open bank account (dummy) & $1.4530^{*}$ & & -0.6840 & -1.7080 & & $-1.5460 *$ \\
\hline Change in share of natural resources exports ${ }^{2}$ & -0.0275 & $0.0978^{* *}$ & & -0.0147 & 0.0594 & \\
\hline Change in share of natural resources exports ${ }^{2}$ & -0.0335 & & $0.1060^{* * *}$ & -0.0147 & & 0.0594 \\
\hline \multicolumn{7}{|l|}{ Fiscal Policy: } \\
\hline Fiscal redistribution & $-0.0842^{* * *}$ & $-0.3280^{* *}$ & & 0.0356 & $-0.7370^{\star \star *}$ & \\
\hline Education spending & $-0.1830^{*}$ & -0.2000 & & -0.3000 & -0.3880 & \\
\hline Education spending & -0.1400 & & $-0.2060^{* *}$ & -0.2470 & & -0.1400 \\
\hline \multicolumn{7}{|l|}{ Other macroeconomic factors: } \\
\hline Financial depth (M2/GDP) & -0.0014 & -0.0018 & & 0.0011 & $-0.0805^{\star * *}$ & \\
\hline Public capital stock & -0.0003 & -0.0055 & & 0.0019 & $-0.0208^{* * *}$ & \\
\hline Private capital stock & $-0.0056^{* * *}$ & $-0.0051^{*}$ & & -0.0038 & $-0.0089^{*}$ & \\
\hline Trade openness & 0.0008 & 0.0031 & & -0.0023 & $-0.0356^{* * *}$ & \\
\hline
\end{tabular}

Source: Authors' calculations.

Note: ${ }^{*} p<0.1,{ }^{* *} p<0.05,{ }^{* * *} p<0.01$

${ }^{1}$ The table summarizes the findings from separate regressions, with the dependent variable being the change in net gini. GDP per capita growth, education inequality, and the change in share of natural resource exports are averaged over the period. All other variables are initial period observations. The results are based on quantle regressions, with initial level of inequality included as an explanatory variable throughout. Interaction terms reflect development level and regional specificities. LIC is a dummy that takes a value of 1 for low and lower-middle income countries as defined by the World Bank and 0 otherwise. SSA is a dummy that takes a value of 1 for subSaharan African countries and is 0 otherwise. The symbols ${ }^{*},{ }^{* *}$, and ${ }^{* * *}$ indicate that the estimated coefficient is statistically significantly different from zero at the 10,5 , and 1 percent level, respectively.

${ }^{2}$ Exports of agricultural raw materials, ores and metals, and fuel as a percentage of total merchandise exports. 
The effect of financial sector deepening does not seem to matter for inequality in the overall sample quantile regressions. This is in line with recent literature findings that at early stages of development, financial sector deepening can aggravate inequality by mainly benefitting higherincome groups that already have financial sector access. For the group of countries that achieved large reductions in inequality (or the 10th quantile declines in inequality), enhancing women's access to financial services seems to have played a role in reducing income inequality mainly for lower-income countries. However, there are differences in some of the variables' relationships with changes in inequality among different country groups, particularly in sub-Saharan Africa.

\section{Implications for sub-Saharan Africa}

In recent years, per capita income growth has not reduced poverty and income inequality in sub-Saharan Africa (Table 3). Indeed, on average for the region and unlike elsewhere, the higher GDP per capita growth appears to have been accompanied by higher inequality. This could be reflecting a possibly transitory relation and/or the omission of relevant control variables. The results on gender inequality suggest a somewhat lower net effect in the case of sub-Saharan Africa, than for low-income countries on average. The variables pertaining to opportunity yield mixed results, with lower education inequality contributing to a net increase in income inequality and improved financial access for women leading to a worsening of inequality in the overall sample quantile regressions. These could be related to the fact that there is a significant skills premium from improving access to education and financial services, which in the early phase lead to a worsening of inequality. However, it should be noted that improved financial access for women were associated with the largest reductions in inequality $\left(10^{\text {th }}\right.$ quantile regressions $)$ in sub-Saharan African countries. Moreover, increased education spending and fiscal redistribution are associated with a reduction in inequality, further emphasizing the point about potential gains from improving both access and the quality of delivery, including by moving away from blunt instruments like universal subsidy programs to targeted policies that increase the progressivity of tax systems and expenditures and reduce possible gender bias.

Structural factors have been associated with higher income inequality in the region. The channels linking growth to inequality in sub-Saharan Africa may be different than in other developing countries, given the importance of commodity price booms in driving growth in a number of sub-Saharan African countries. Indeed, increases in dependence on trade in natural resources are found to be associated with increases in economic inequality over the same period. This result is mainly driven by oil exports (not reported in the table). The region's continued high fertility rate slows the rise in the share of the working age population. This underscores the importance of accelerating the demographic transition by raising investment in human capital (April 2015 Regional Economic Outlook: Sub-Saharan Africa). 


\section{Conclusions}

We find that income and gender inequality, including from legal gender-related restrictions, impede growth mainly in countries at earlier stages of development, with large growth losses in sub-Saharan Africa. Examining the effects of gender inequality and income inequality jointly in a large global panel over the last two decades, we find that further progress in reducing income and gender inequality could deliver significant sustained growth dividends, in particular for lowincome countries. The result that both gender inequality and income inequality matter for growth implies that gender inequality affects growth via different channels than income inequality. The implications for sub-Saharan Africa are particularly striking. Despite some progress in reducing income and gender inequality in sub-Saharan Africa over the last twenty years, the region continues to be characterized by comparatively high levels of inequality. The empirical analysis highlights that annual economic growth in sub-Saharan African countries could be higher by as much as 0.9 percentage points if inequality of gender and income was reduced to the levels observed in the fast-growing ASEAN region with variations across country groups. This contrasts with the findings for Latin America and the Caribbean where gender inequality does not appear to be a main contributor to the region's growth differentials with ASEAN.

Our results suggest that both structural factors and policies have been driving changes in inequality over time, but the relevant factors differ by region and level of development. GDP per capita growth, the private capital stock, education spending, gender inequality, the share of the working age population and fiscal redistribution appear as generally related to changes in income inequality in the global sample. High levels of income inequality in sub-Saharan Africa appear partly driven by the structural features of its countries but fiscal and financial sector policies that influence the access of low-income households and women to opportunities also matter. The latter evidence suggests that policies, if carefully designed, could help with reducing inequality. However, given that inequality varies from country to country and in view of the multiple factors driving inequality, policies must be tailored to country-specific situations and take into account administrative capacity and potential tradeoffs. In particular, there is a need to ensure that policies aimed at reducing income inequality are carefully designed so that they themselves do not adversely affect economic growth.

Overall, the paper's findings highlight the importance for countries, particularly in subSaharan Africa, to make progress with reducing income and gender inequalities to achieve sustained growth. In this context the fact that the recently launched SDGs explicitly recognize income and gender inequality as separate goals is encouraging. This shows that governments around the world, including in sub-Saharan Africa, recognize that these are important areas for further progress to be made to improve living standards and for macroeconomic stability. Once the Millennium Development Goals were announced, countries started to make efforts to achieve the goals for example leading to considerable progress in improving primary education attainment. Now countries must build on this impetus to make progress in reducing income and gender inequalities. Also, while legal restrictions and other gender gaps are often the consequence of social norms, an issue that goes beyond the scope of this paper, the removal of legal restrictions and increasing the accessibility of education and healthcare may themselves provide an impetus for social norms to change. 


\section{References}

Amin, Mohammad, Veselin Kuntchev, and Martin Schmidt. 2015. "Gender Inequality and Growth: The Case of Rich vs. Poor Countries." World Bank Policy Research Working Paper; 7172, World Bank, Washington.

Balakrishnan, R., C. Steinberg, and M. Syed. 2013. "The Elusive Quest for Inclusive Growth: Growth, Poverty and Inequality in Asia.” IMF Working Paper 13/152, International Monetary Fund, Washington.

Barro, R. 2000. "Inequality and Growth in a Panel of Countries.” Journal of Economic Growth, Vol. 5 (1): 5-32.

Beegle, Kathleen, L. Christiansen, A. Dabalen, and I. Gaddis. 2016. "Poverty in a Rising Africa: Overview." World Bank, Washington.

Benabou, Roland. 1996. "Inequality and Growth", National Bureau of Economic Research Macroeconomics Annual, Vol. 11, pp.11-74. Ben Bernanke and Julio Rotemberg (eds) Cambridge: MIT Press,

Berg, A., and J. Ostry. 2011. "Inequality and Unsustainable Growth: Two Sides of the Same Coin?” IMF Staff Discussion Note 11/09, International Monetary Fund, Washington.

Bhorat, H., K. Naidoo, and K. Pillay. 2015. "Growth, Poverty and Inequality Interactions in Africa. An Overview of Key Issues," Mimeo, Inc.

Bucellato, T., M. Alessandrini. 2009. "Natural Resources: A Blessing or a Curse? The Role of Inequality." Discussion Paper 98. Center for Financial Management Studies.

Castello-Climent, A. 2010. "Inequality and Growth in Advanced Economies: an Empirical Investigation," Journal of Economic Inequality, 8 (3): 293-321.

Castelló-Climent, A. and R. Doménech. 2014. "Human Capital and Income Inequality: Some Facts and Some Puzzles," BBVA Working Paper 12/28, Madrid, March.

Christiansen, L., L. Demery, J. Kuhl. 2007. “The Role of Agriculture in Poverty Reduction: an Empirical Perspective.” World Bank Policy Research Working Paper 4013, World Bank, Washington.

Cingano, F. 2014. "Trends in Income Inequality and its Impact on Economic Growth." OECD Social, Employment and Migration Working Papers, No. 163, World Bank, Washington.

Corak, M. 2013. "Income Inequality, Equality of Opportunity, and Intergenerational Mobility," Journal of Economic Perspectives, 27 (3): 79-102.

Cuberes, David and Teignier, Marc. 2015. "Aggregate Costs of Gender Gaps in the Labor Market: A Quantitative Estimate." Forthcoming in the Journal of Human Capital.

Dabla-Norris, E., K. Kochhar, N. Suphaphidat, F. Ricka, E. Tsounta. 2015. "Causes and Consequences of Inequality: A Global Perspective." IMF Staff Discussion Note 15/13, International Monetary Fund, Washington. 
Demirgüç-Kunt, Asli, Leora F Klapper, and Dorothe Singer. 2013. "Financial Inclusion and Legal Discrimination Against Women: Evidence from Developing Countries." World Bank Policy Research Working Paper 6416, World Bank, Washington.

Elborgh-Woytek, K., M. Newiak, K. Kochhar, S. Fabrizio, K. Kpodar, P. Wingender, B. Clements, and G. Schwartz. 2013. "Women, Work, and the Economy: Macroeconomic Gains from Gender Equity." Staff Discussion Note 13/10, International Monetary Fund, Washington.

Esteve-Volart, Berta. 2004. "Gender Discrimination and Growth: Theory and Evidence from India.” s.1.: LSE STICERD Research Paper No. DEDPS 42, 2004.

Galor, O., and J. Zeira. 1993. "Income Distribution and Macroeconomics." The Review of Economic Studies, 60 (1): 35-52.

Gonzales, C., S. Jain-Chandra, K. Kochhar, and M. Newiak. 2015a. "Fair Play: More Equal Laws Boost Female Labor Force Participation.” IMF Staff Discussion Note 15/02, International Monetary Fund, Washington.

Gonzales, C., S. Jain-Chandra, K. Kochhar, M. Newiak, and T. Zeinullayev. 2015 b. "Catalyst for Change: Empowering Women and Tackling Income Inequality." IMF Staff Discussion Note 15/20, International Monetary Fund, Washington

Greenwood, J., and B. Jovanovic. 1990. "Financial Development, Growth, and the Income Distribution.” Journal of Political Economy 98: 1076-107.

IMF, 2014. "Fiscal Policy and Income Inequality." IMF Policy Paper. (Washington, D.C.: International Monetary Fund). . 2015a. Regional Economic Outlook: Sub-Saharan Africa. April 2015, International Monetary Fund, Washington.

_. 2015b. "Making Public Investment More Efficient," IMF Policy Paper, (Washington, D.C.: International Monetary Fund).

http://www.imf.org/external/np/pp/eng/2015/061115.pdf

Klasen, S. 1999. "Does Gender Inequality Reduce Growth and Development? Evidence from Cross-Country Regressions," Policy Research Report, Engendering Development, Working Paper 7, World Bank, Washington.

Klasen, S., and F. Lamanna. 2009. "The Impact of Gender Inequality in Education and Employment on Economic Growth: New Evidence for a Panel of Countries." Feminist Economics, Taylor \& Francis, 15(3): 91-132.

Kuznets, S., 1955, "Economic Growth and Income Inequality," American Economic Review, 45: $1-28$.

Mitra, A., J. Bang, and Biswas, A. 2015, “Gender Equality and Economic Growth: Is it Equality of Opportunity or Equality of Outcomes?" Feminist Economics, 21(1): $110-135$.

Neves, P.C., and S. M. T. Silva, 2014, "Inequality and Growth: Uncovering the Main Conclusions from the Empirics," The Journal of Development Studies, 50 (1): 1-21. 
Ostry, J., A. Berg, and C. Tsangarides. 2014. "Redistribution, Inequality, and Growth." IMF Staff Discussion Note 14/02, International Monetary Fund, Washington.

Ravallion, M. 2001. "Inequality Convergence,” World Bank Policy Research Working Paper, July. World Bank, Washington.

Sala-i-Martin, X. 2002. "The World Distribution of Income (Estimated from Individual Country Distributions)," NBER Working Paper Series, No. 8933, May.

Soares, Rodrigo R. 2005. "Mortality Reductions, Educational Attainment, and Fertility Choice." American Economic Review 95 (3): 580-601.

Soares, Rodrigo R., and Bruno L. S. Falcao. 2008. "The Demographic Transition and the Sexual Division of Labor," Journal of Political Economy 116 (6): 1058-1104.

Stotsky, J. G. 2006. “Gender and its Relevance to Macroeconomic Policy: A Survey.” IMF Working Paper No. 06/233, International Monetary Fund, Washington.

World Bank. 2012. World Development Report: Gender Equality and Development. World Bank, Washington.

- 2013. "Women, Business and the Law 2013. Removing Restrictions to Enhance Gender Equality,' World Bank/International Finance Corporation, Washington. 


\section{APPEndiX 1. COUnTRY COVERAGE}

This section specifies the countries used in the empirical analyses in the paper. Owing to data constraints, not all the countries are included in all the regressions.

\section{High income countries, as defined by the World Bank:}

United States, United Kingdom, Austria, Belgium, Denmark, France, Germany, Italy, Luxembourg, Netherlands, Norway, Sweden, Switzerland, Canada, Japan, Finland, Greece, Iceland, Ireland, Malta, Portugal, Spain, Australia, New Zealand, Chile, Uruguay, Barbados, Trinidad and Tobago, Cyprus, Israel, Hong Kong SAR, China, Korea Rep., Singapore, Russian Federation, Czech Republic, Slovak Republic, Estonia, Latvia, Lithuania, Croatia, Slovenia, and Poland.

\section{Middle income countries are those defined by the World Bank as "Upper Middle Income countries":}

Turkey, South Africa, Argentina, Brazil, Colombia, Costa Rica, Dominican Republic, Ecuador, Mexico, Panama, Peru, Venezuela RB, Belize, Jamaica, St. Lucia, Suriname, Iran Islamic Rep., Iraq, Jordan, Malaysia, Maldives, Thailand, Algeria, Angola, Botswana, Gabon, Mauritius, Seychelles, Namibia, Tunisia, Fiji, Marshall Islands, Azerbaijan, Belarus, Albania, Kazakhstan, Bulgaria, China, Turkmenistan, Serbia, Montenegro, Hungary, Macedonia FYR, Bosnia and Herzegovina, and Romania.

\section{Low income countries are those defined by the World Bank as "Lower Middle Income" or "Low Income" countries: \\ Bolivia, El Salvador, Guatemala, Haiti, Honduras, Nicaragua, Paraguay, Guyana, Syrian Arab Republic, Egypt Arab Rep., Yemen Rep., Afghanistan, Bangladesh, Bhutan, Cambodia, Sri Lanka, India, Indonesia, Lao PDR, Nepal, Pakistan, Philippines, Vietnam, Djibouti, Burundi, Cameroon, Cabo Verde, Central African Republic, Chad, Comoros, Congo Rep., Congo Dem. Rep., Benin, Ethiopia, The Gambia, Ghana, Guinea-Bissau, Guinea, Côte d'Ivoire, Kenya, Lesotho, Liberia, Madagascar, Malawi, Mali, Mauritania, Morocco, Mozambique, Niger, Nigeria, Zimbabwe, Rwanda, São Tomé and Príncipe, Senegal, Sierra Leone, Sudan, Swaziland, Tanzania, Togo, Uganda, Burkina Faso, Zambia, Papua New Guinea, Micronesia Fed. Sts., Armenia, Georgia, Kyrgyz Republic, Moldova, Tajikistan, Ukraine, Uzbekistan, and Mongolia.}




\section{Appendix Table 1. Description of Variables for the Regressions Assessing the Growth Effects of Income and Gender Inequality}

\begin{tabular}{|c|c|c|}
\hline Variable & Description & Source \\
\hline Initial income inequality (t20/b40)1 & $\begin{array}{l}\text { Ratio of income distribution at the top } 20 \\
\text { relative to that of the bottom } 40 \text { percent of } \\
\text { population. }\end{array}$ & $\begin{array}{l}\text { Primarily World Development } \\
\text { Indicators (WDI) database, augmented } \\
\text { by the UNU-WIDER database. }\end{array}$ \\
\hline Initial income inequality (Gini) $)^{1}$ & $\begin{array}{l}\text { The traditional Gini measure of inequality. In } \\
\text { this paper, we use "net" Gini but find similar } \\
\text { results with "market" Gini. }\end{array}$ & $\begin{array}{l}\text { The Standardized World Income } \\
\text { Inequality Database (SWIID v.5.0). }\end{array}$ \\
\hline $\begin{array}{l}\text { Initial income share of middle } \\
\text { class }\end{array}$ & $\begin{array}{l}\text { The sum of income shares of the third and } \\
\text { fourth quintiles of population. }\end{array}$ & $\begin{array}{l}\text { Primarily World Development Index } \\
\text { (WDI), augmented by UNU-WIDER } \\
\text { database. }\end{array}$ \\
\hline Lagged gender inequality ${ }^{1}$ & $\begin{array}{l}\text { Index calculated using the UN methodology, } \\
\text { which covers the } 1990-2010 \text { periods. }\end{array}$ & $\begin{array}{l}\text { IMF staff estimates. Details are } \\
\text { reported in Gonzales et al., 2015b. }\end{array}$ \\
\hline Female legal inequity ${ }^{1}$ & $\begin{array}{l}\text { The sum of six binary indicators representing } \\
\text { existence of restrictions on selected women's } \\
\text { legal rights. Takes on value of } 0 \text { (no } \\
\text { restrictions) to } 6 \text { (all selected restrictions on } \\
\text { rights). }\end{array}$ & $\begin{array}{l}\text { The World Bank's Women, Business } \\
\text { and the Law (WBL) database. }\end{array}$ \\
\hline Initial income per capita & $\begin{array}{l}\text { The logged real GDP per capita in the first } \\
\text { year in each five-year period. }\end{array}$ & The Penn World Tables (PWT v.8.0). \\
\hline Fixed capital investment & $\begin{array}{l}\text { Gross fixed capital formation in percent of } \\
\text { GDP, averaged over five-year periods. }\end{array}$ & $\begin{array}{l}\text { Primarily from the PWT, with some } \\
\text { augmentation from the World Bank's } \\
\text { WDI. }\end{array}$ \\
\hline Schooling & $\begin{array}{l}\text { Average years of schooling (in each five-year } \\
\text { period) for the population aged } 15 \text { and } \\
\text { above. }\end{array}$ & Barro-Lee database. \\
\hline Dependent population growth & $\begin{array}{l}\text { Average annual percentage change in the } \\
\text { non-working age population (under } 15 \text { or } \\
\text { above } 64 \text { ). }\end{array}$ & The UN Population database. \\
\hline Infrastructure index & $\begin{array}{l}\text { Composite index based on electricity } \\
\text { consumption, access to water, and access to } \\
\text { any type of phones. A higher value } \\
\text { corresponds to an overall greater level of } \\
\text { infrastructure. }\end{array}$ & $\begin{array}{l}\text { Electricity consumption is taken from } \\
\text { the IEA database. Access to water and } \\
\text { telephones are taken from the WDI } \\
\text { database. }\end{array}$ \\
\hline High inflation & $\begin{array}{l}\text { A dummy variable with value } 1 \text { if average } \\
\text { annual inflation in consumer prices over a } \\
\text { given five-year period is more than } 15 \\
\text { percent. }\end{array}$ & $\begin{array}{l}\text { IMF World Economic Outlook } \\
\text { database. }\end{array}$ \\
\hline Change in terms of trade & $\begin{array}{l}\text { The average annual change in the terms of } \\
\text { trade over the five year period (constant } \\
\text { LCU). }\end{array}$ & The World Bank WDI database. \\
\hline Institutional quality & $\begin{array}{l}\text { A composite index of political risk; higher } \\
\text { values of the index (ranging } 0-100 \text { ) imply } \\
\text { better quality of institutions and hence lower } \\
\text { risk. }\end{array}$ & $\begin{array}{l}\text { This is the political risk index from the } \\
\text { International Country Risk Guide } \\
\text { (ICRG). }\end{array}$ \\
\hline
\end{tabular}

\footnotetext{
${ }^{1}$ Interactions of these variables with a low income country dummy variable (LIC) are also included in selected models.
} 


\section{Appendix Table 2. Description of Variables for the Regressions Assessing the Determinants of Change in Income Inequality}

\begin{tabular}{|c|c|c|}
\hline Variable & Description & Source \\
\hline Change in net Gini & $\begin{array}{l}\text { The difference of the net Gini in levels over each } 5 \text {-year } \\
\text { interval. In instances where a country does not have } \\
\text { both an initial and an end value of Gini in a given } \\
\text { period, there is a missing value. }\end{array}$ & $\begin{array}{l}\text { The Standardized World Income } \\
\text { Inequality Database (SWIID v.5.0). }\end{array}$ \\
\hline $\begin{array}{l}\text { Initial income } \\
\text { inequality (Gini) }\end{array}$ & The initial value of the net Gini for a particular period. & $\begin{array}{l}\text { The Standardized World Income } \\
\text { Inequality Database (SWIID v.5.0). }\end{array}$ \\
\hline Share of agriculture & $\begin{array}{l}\text { The percentage share of the agriculture sector in total } \\
\text { GDP. }\end{array}$ & The World Bank WDI database. \\
\hline $\begin{array}{l}\text { Share of working-age } \\
\text { population }\end{array}$ & $\begin{array}{l}\text { The percentage of working age (15-64) population in } \\
\text { the economy. For each period, we take the value from } \\
\text { the initial year. }\end{array}$ & UN Population database. \\
\hline Education inequality & Education Gini & $\begin{array}{l}\text { Castelló-Climent and Doménech (2014) } \\
\text { constructed from the latest education } \\
\text { database by Barro and Lee. }\end{array}$ \\
\hline Fiscal redistribution & $\begin{array}{l}\text { The difference between market Gini and net Gini. For } \\
\text { each period, the value from the initial year is taken. }\end{array}$ & $\begin{array}{l}\text { The Standardized World Income } \\
\text { Inequality Database (SWIID v.5.0). }\end{array}$ \\
\hline Education Spending & $\begin{array}{l}\text { The percentage of public spending allocated to } \\
\text { education. For each period, the value from the initial } \\
\text { year is taken. }\end{array}$ & The World Bank WDI database. \\
\hline Financial depth & $\begin{array}{l}\text { The ratio of broad money (M2) to GDP. For each } \\
\text { period, the value from the initial year is taken. }\end{array}$ & The World Bank WDI database. \\
\hline \multirow[t]{2}{*}{$\begin{array}{l}\text { Women's financial } \\
\text { inclusion }\end{array}$} & $\begin{array}{l}\text { A dummy variable with a value of } 1 \text { if women have the } \\
\text { ability to open bank accounts }\end{array}$ & $\begin{array}{l}\text { The World Bank's Women, Business and } \\
\text { the Law (WBL) database. }\end{array}$ \\
\hline & $\begin{array}{l}\text { Average annual percentage change in the non-working } \\
\text { age population (under } 15 \text { or above } 64 \text { ). }\end{array}$ & The UN Population database. \\
\hline Public capital stock & $\begin{array}{l}\text { The variable is an estimate of general government } \\
\text { capital stock, constructed based on general } \\
\text { government investment flows (in } 2005 \text { dollar prices). }\end{array}$ & $\begin{array}{l}\text { IMF Investment and Capital Stock } \\
\text { database. See } \\
\text { (http://www.imf.org/external/np/fad/publici } \\
\text { nvestment/data/info.pdf) "Estimating } \\
\text { Public, Private, and PPP Capital Stocks". }\end{array}$ \\
\hline Private capital stock & $\begin{array}{l}\text { The variable is an estimate of private capital stock, } \\
\text { constructed based on private investment flows (in } 2005 \\
\text { dollar prices). For each period, the value from the initial } \\
\text { year is taken }\end{array}$ & $\begin{array}{l}\text { IMF World Economic Outlook database. . } \\
\text { See } \\
\text { (http://www.imf.org/external/np/fad/publici } \\
\text { nvestment/data/info.pdf) "Estimating } \\
\text { Public, Private, and PPP Capital Stocks". }\end{array}$ \\
\hline Trade openness & $\begin{array}{l}\text { The sum of total exports and imports as a percentage } \\
\text { of GDP }\end{array}$ & IMF World Economic Outlook database. \\
\hline
\end{tabular}

